\title{
READING BODDO'S BODY: CROSSING THE BORDERS OF RACE AND SEXUALITY IN WHITMAN'S “HALF-BREED”
}

\author{
Thomas C. GanNon
}

He was deformed in body - his back being mounted with a mighty hunch, and his long neck bent forward, in a peculiar and disagreeable manner . . . . His face was the index to many bad passions - which were only limited in the degree of their evil, because his intellect itself was not very bright . . . . Among the most powerful of his bad points was a malignant peevishness, dwelling on every feature of his countenance . . . The gazer would have been at some doubt whether to class this strange and hideous creature with the race of Red Men or White-for he was a half-breed, his mother an Indian squaw, and his father some unknown member of the race of the settlers.

-Walt Whitman, "The Half-Breed: A Tale of the Western Frontier"1

[T] he question of the abject is very closely tied to the question of being aboriginal. . . .

-Gayatri Chakravorty Spivak ${ }^{2}$

\section{The "Noble Savage" and the "Monstrous Abortion"}

"They showed the child of the Indian girl-my son!-I almost shrieked with horror at the monstrous abortion! The mother herself had died in giving it birth. No wonder." ("The Half-Breed" [EPF 272])

WhITMAN's EARLY TALE, “The Half-Breed" (1846), with its contrived plot, sometimes ludicrous melodrama, and blatant appeal to an audience primed for frontier exoticism, would hardly be included on many people's " $A$ " lists of required Whitman readings. And yet the relatively scant critical attention it has received from scholars is still rather surprising, given the current interest in cultural studies of race and ethnicity. Indeed, the title character's sheer physical status as a mixed-blood stuck between the worlds of "White" and "Red" seems to beg for an analysis of the work in terms of recent ideas of racial and cultural "hybridity." William J. Scheick would read Boddo as simply "the passionate, revengeful hunchback half-blood," whose deformity and moral degeneracy portray the "unnaturalness"-in Whitman's view-of interracial union. ${ }^{3}$ But might not the title character's racial ambiguity allow for a consequent ambiguity of meaning, and his mixed-race "body" thus serve 
as a heterogeneous, contestatory site of competing discourses, perhaps even producing its own "discourse of rebellion," in Michael Moon's phrase (80)? ${ }^{4}$ The half-breed Boddo would thus not only serve as the "immediate instrument of the friction between the races" (Scheick 37), but also as the liminal site or border upon which the encounter of discordant cultural discourses is negotiated.

Some of the discussions of "The Half-Breed" that do exist seem to get the story only half-right, as it were. It may be symptomatic of a continuing Euro-American uncomfortableness with racial mixing that David S. Reynolds finds the novella's plot "too tangled to be summarized" - as, in the story, Boddo's own "blood" is too "mixed up" to be culturally viable? Reynolds should have stopped there, for his own summary is so "tangled" that he goes on to identify one of the tale's fullblood Natives, Arrow-Tip, as the "wrongly accused half-breed" who "is tragically hanged." (In point of fact, Boddo is the half-breed, whose Iago-like machinations of revenge lead to the hanging of Arrow-Tip.) Scheick rather muddles the white/Native American issue in another way, by discussing Boddo as, above all, an emblem of Southern fears of whiteblack miscegenation (36-38), in line with various readings of Whitman's early or intermittent sympathy for the South. As for Native Americans, Whitman's view is characterized as follows: since "racial separation" is an "unalterable natural law," and the results of racial inter-marriage are so "grotesque" and "unnatural," Native Americans are doomed to extinction (37). But at last, while Scheick's move to Southern racist attitudes yields an interesting cultural reading, it also sidesteps the real white-Indian interaction of Whitman's plot.

Before dealing with Boddo himself as a split-race figure, I will devote the rest of this introduction to the splitting of the Native American per se that occurs in this tale, a dichotomy that admittedly lends support to previous readings of Boddo as a monolithic figure of evil. Following Ed Folsom's discussion of the deep "ambivalence" that Whitman felt towards Native Americans, an ambivalence based largely on both positive and negative stereotypes, ${ }^{6} \mathrm{I}$ would suggest that the "aborigine" in this story is indeed split into such a positive/negative polarity. Boddo is thus the site of projection for the view of the Indian as barbaric monster and devil, while the pure-bloods in the tale, Arrow-Tip and his brother, the Deer, are rendered as the "noble savages" of a predominantly positive racial stereotyping. (Whitman's fiddling with the story's title might be significant in this regard: the shift of emphasis entailed in the change from "Arrow-Tip" [1845] to "The Half-Breed" [1846] also signals a corresponding shift from "noble" and "good" to "degenerate" and "evil" [EPF 257n]).

If the Native American was, in part, "synonymous with authenticity" for Whitman (Folsom 72), Arrow-Tip, the proud, stoic friend of the villagers, is the tale's inscription of such authenticity and nobility. 
Prior to the illness that brings him back to the village of Warren, he was "one of the finest specimens of the Red People"; and during his later incarceration, he whiles his time away "preserving a calm and lofty aspect" (EPF 263, 284) - to the frustration of both his white accusers and the reader. But such a polar idealization is always fraught with gaps. Arrow-Tip, alone in his nobility except for occasional audiences with his brother, is, like most of Whitman's solitary Indian figures, an "admirable noble vestige" of a great, autochthonous race; but Whitman's description of Indians in groups (or "swarms") was usually less glowing. Furthermore, Arrow-Tip's "vestigial" status and eventual death are also symptomatic of an ambivalent author who considered Indians "noble" but at last "doomed."

Arrow-Tip's taciturnity reveals another hole in the "positive" stereotype. $\mathrm{He}$ is "silent and haughty," with the "apathy" of a "dumb brute" (EPF 284). To the accusation that his brother absconded with the "murdered" victim's body, he has "no answer but a glance of scorn" for such an insult to his tribal mores (285). Taciturn, too, are his entire people, apparently, as the narrator notes Arrow-Tip's membership in a race of "laconic" and "sturdy stoics," and comments upon the "general apathy and haughtiness of the savage character" $(287,288)$. Arrow-Tip is just as "lofty" and "calm" on the scaffold (290), of course, as the narrator exclaims, "What wondrous power those rude savages have over the expression of their features!" (289). (Smug editorial racist interjections like "rude savages" and "dumb brutes" also undercut any thoroughly positive reading of Arrow-Tip as "noble savage.") The author is at last ambivalent even about this "proud" laconism, this alien reluctance for words that Whitman, a compulsive user of words, could never really understand (Folsom 91) ${ }^{8}$ It bears noting, too, that Arrow-Tip's silence about the events of the (non-) "murder" is a major reason for his eventual execution. When he finally tells the story of his argument with Peter Brown, the narrator's qualification of this taciturnity is an obvious ploy at plot development: "it is an error to suppose that our American Indians invariably retain their sedateness" (EPF 285). But Arrow-Tip's set speech here is merely the exception that proves the rule, an out-ofcharacter plot device to get the story told.

Despite such imploding contradictions within Whitman's idealization of Arrow-Tip, the story's pure-blood is portrayed above all as honest, noble, and endowed with a close-to-the-land authenticity. The negative racism against the Native American, on the other hand, is projected almost exclusively upon Boddo, just as he also embodies the "monstrous" nature of any mixing of the races. Our hunchback comes "limping" into the story like some goat-footed figure bent on some mischievous errand from the underworld (258). Not only is he a thief and a murderer (through his conspiracy of silence and lying), but he is also 
something of a hedonist, with an apparent love of rum and pork (259). $\mathrm{He}$ is blessed with a "stupid obstinacy" and indolence, and his main means of communication, it would seem, is a sinister glare of "deviltry and hate" $(268,279,269)$. As his own father puts it, he is indeed a "'monstrous abortion!"” (272).

But Boddo is a monster, at last, because he is a half-breed. If my bipolar reading seems ultimately to fall apart in places (the fate of all binaries), it is because Boddo is an overdetermined site of several discourses. Thus Boddo can serve, on one level, as a projection for one half of white Americans' ambivalent and polarized mythologization of the Native American. On another level, Boddo is further demonized as the site of miscegenation, with all the possibilities of discursive resistance that such a hybridity entails. Boddo's is a "body," at last, on the "frontier" (literally and metaphorically) or "border" (culturally and psychologically). If Whitman would eventually use the "body" in the Leaves of Grass as the "site where the issues of representation and political power intersect," serving as an "epistemological clearinghouse for managing one's relations with" society (Phillips 302), then Boddo's characterization could be viewed as a practice ground for such an "embodying" project. As for the story's very setting on the frontier, Amy Kaplan's move towards cultural hybridity is relevant here, as she traces the concept of the "frontier" from a "vacant space of the wilderness" to "a bloody battlefield of conflict and conquest" to, at last, "a site of contacts, encounters, and collisions that produce new hybrid cultures." ${ }^{10} \mathrm{I}$ would suggest that these notions of the "body" and the hybrid "border" can be combined by reading Boddo's body as just such a site of hybridity and contestation.

\section{Boddo as Racial Border Figure: "The Half-Breed" E Racial Hybridity}

Boddo scowled, but it was of no avail. He was in the power of the lawless ones, and could not escape. ("The Half-Breed" [EPF 258])

While Boddo himself is a crucial "emboddoment" of Whitman's and his age's views of miscegenation, these attitudes might be best introduced by way of two other, more well-known, treatments of the subject in his corpus. In his novel Franklin Evans (1842), Whitman ventures a "daring" treatment of miscegenation, according to Reynolds, as the future Good Gray Poet "revels in the perverse results of the flawed marriage" between Evans and the Creole Margaret (97). The revelatory multiple encodings that occur in this novel will be discussed later, but one must note immediately that the mixed-blood Margaret, both murderess and suicide, is painted in the same dark moral shades as Boddo (though one can perhaps "secretly" more empathize with her treatment and plight). Her sensuality - her "luscious and fascinating appearance," 
her "voluptuous eyes"-are markers, at last, of her moral degeneracy, and Evans's "unnatural" marriage act can only be explained as a "drunken rashness."

In contrast, the marriage of the "trapper" and the "red girl" in "Song of Myself" ing," a merger of "racial harmony and love": significantly, this union of "a racially mixed couple" is the only "extended wedding scene" in Leaves of Grass. The trapper's ready gun is there for "defending" his blushing bride, who is herself a figure of "statuesque beauty" (Reynolds 291). However, the description of the "red" bride's "coarse straight locks," smacking as it does of an implicit trait-descriptive racism, doesn't quite qualify as "statuesque" to this reader, and "statue-esque" itself seems a rather loaded, cigar-store-Indian-like appellation. And while Whitman himself does employ the phrase "voluptuous limbs," Margaret, too, had "voluptuous eyes," and we know the fate of her marriage, and the scurrility of her morals. The gun, moreover, seems a little more ominous than Reynolds describes it, and I'm more apt to agree with SánchezEppler's reading, in which the firearm (of the 1855 text) connotes "the precariousness and explosiveness of interracial contact" (77). But there seems little doubt that the passage at least intends a more positive signification (although, perhaps tellingly, the episode stops short of any "halfbreed" birth)-perhaps an example, then, of the poet's later holistic imaginative impulse to marry "master and slave."

Indeed, Sánchez-Eppler would even see the trope of miscegenation as an originary site of Whitman's "poetic goal of healing radical divisions, social and personal," his democratizing gesture to "stand between" the hierarchy of "master and slave" and to "reconcile bodily differences." 13 However, Whitman's attempt at poetic mediation via miscegenation is finally a failure, a project that deconstructs itself. ${ }^{14}$ Boddo is obviously a lot closer to Margaret, as a figure of degeneracy, but I hope to show eventually that his ostensible abjection also deconstructs itself, as the colonial project of Othering creates cracks and fissures in the dominant discourse that allow the Other to "speak back."

As we have seen, Scheick would have Boddo be a completely "dark" and monstrous Caliban figure-as viewed from Prospero's colonizing gaze, of course. ${ }^{15}$ Folsom positions Boddo's status in diametrical opposition to the trapper-and-bride passage, as the "fragmented, dark other side" of "Indian-white coupling." Boddo himself is the "deformed and deceitful amalgam of the worst qualities of both races": in sum, "Whitman felt that 'amalgamation' of the races was not possible, would result only ... in monsters like Boddo" $(74,89)$. "Amalgamation" is certainly a key term in such a discussion, as Robert Young's discussion of nineteenth-century conceptualizations of "hybridity" demonstrates. At the time, white scholars pondered where various groups of human fit 
on the hierarchical links of the "Great Chain of Being,"16 and debated whether other "races" might actually be different species, and wondered what could be made at all of a "hybrid," mixed-race person . . . or was it a mixed-species person (6-9)? Among the resultant theories was the "negative version of the amalgamation thesis," which claimed that "miscegenation produces a mongrel group" that is "merely a corruption," a motley crew of the "degenerate and degraded." 17 Given such explanations, it is no surprise that, within that Great Chain of Being, no humans were more "demonized" than "those of mixed race" (180).

And so is Boddo vilified as the stock villain of his story, in part because of the others' anxious inability to "class" him as "Red" or "White" (EPF 258), as an entity indefinitely positioned on the "Chain." And yet there are places in the tale in which an inkling of sympathy for Boddo peeks through the cracks, best evidenced in his initial appearance before the crowd of cruel, taunting school children (258-261). Here the children's behavior can be read as paradigmatic of the colonizing act itself, with its overt display of power and status, and the covert manoeuvres through which it deconstructs itself. As the "mischievous" children "tormentingly" surround him, Boddo feels as if he is "in the power of the lawless ones" (258). As interpellated subjects of the white Law of the Father, the children are hardly "lawless" (leaving the literal reference to their impulsive youth aside), but rather much more within, and accepted by, this Law than Boddo is; even their cruelty might be seen as the will-to-power that the colonizer necessarily brings to the colonial situation. But the apparently innocuous reference to the "lawless ones" might also be read, from Boddo's point of view, as a counterhegemonic utterance erupting into the "Law" of this hegemonic text, calling the "Law" of colonialism - and the Othering of the abject-into ethical question.

As another act of rebellious resignification on Boddo's part, he calls the boys at last "Devils!"” (259), as if to contest the text's more usual demonization of Boddo himself through most of the story. Thus have the colonized often combatted the colonizers, turning the colonizing culture's signifiers on their head, in an attempt to create a space for resistance: "reverse the direction of a binary opposition and you discover the violence" of the Western will-to-power, the "epistemic violence of imperialism" (Spivak 8, 95). The whites are not law-bringers, but the "lawless"; not bearers of the true religion, but "Devils" instead. Whitman would make explicit elsewhere his own awareness that "Names are the turning point of who shall be master-."18 Boddo's own appellative reversals can thus be read as attempts at master-y. Later in the story, Boddo sneeringly says to Father Luke, "What they say in the village is [as] often false as true"" (EPF 279). To continue my translation: what the whites bring is not truth-but falsehood. ${ }^{19}$ 
Aside from these intermittent instances of dialogic rebellion, Boddo's position in the "middle" (or on the "border") of colonial discourse enables one to also read him as the contestatory site of the colonizer's fear and guilt regarding both miscegenation and the racial "Other." Homi Bhabha's neo-Lacanian analysis of the colonial psyche as itself the product of an ambivalent process of desire and fear, of identification and aggression, ${ }^{20}$ goes far in explaining Boddo's role as object of fear and violence (e.g., the children's cruelty) in the tale. But first, this psychoanalytical schema also might explain the "splitting" that exemplifies Whitman's own general ambivalence towards the Native American. The fetishist desire that drove the poet to identify his own poetic project as an "indigenous" one and allowed him to privilege the Indian's authenticity (Folsom 72, 82-83) led to Arrow-Tip as "noble savage" and to Whitman's own "barbaric yawp." But his concomitant fear regarding the inassimilable "difference" of the colonized Other led to Boddo, and Margaret-and the trapper's ready gun. ${ }^{21}$

In his discussion of U.S.-Mexican relations (and again using the "border" as a metaphoric meeting of cultures), Bhabha notes both the "fear/desire of miscegenation," and the "American border as cultural signifier of a pioneering, male 'American' spirit always under threat from races and cultures beyond the border or frontier" (69). As we have seen, the fear of miscegenation has its fetishist inverse, the desire for such a union, a cultural desire with a long history in an American lore, from Jefferson on. But the imperial (and male) "I" also feels a deep ontological anxiety in the presence of the colonized Other, and must react aggressively. And so the "objective of colonial discourse is to construe the colonized as a population of degenerate types on the basis of racial origin, in order to justify conquest" (70). But since the drive of identification and appropriation has already co-opted the mythic "noble savage," the white-Indian mixed-blood is left as the site of the compensatory drive of fear in the face of difference, and thus the epitome of degeneration and the most apt object of fear, loathing, and colonial aggression. At last, if Boddo's "face was the index to many bad passions" (EPF 258), his whole being was also a site of such negative, and ultimately recuperative, projections.

But those "bad passions" were those of the whites, at last. Indeed, the colonizer's own cultural and physical violence against the "noble" Native American created a cognitive dissonance that was readily displaced upon a figure such as Boddo, who is "made" the murderer of Arrow-Tip and whose Iago-like guile could easily be read (if one were prone to be so reductive, essentialist, and racist) as the product of his white "blood"- since he is, in terms of the "negative amalgamation" theory, the "worst" of both races. The plot displacement perceived here is purposeful: by making Boddo the murderer, the whites (and white 
author) are absolved of immediate guilt, and the naked facts of the U.S. whites' nearly successful attempt at an "ethnic cleansing" of the Native American are thereby mystified, occluded. ${ }^{22}$ At last, "What they say in the village is [as] often false as true."

As a segue to this essay's next section, let me recall again Whitman's change of titles for the story, from "Arrow-Tip" to "The Half-Breed." Just having come from a discussion of colonial desire and fetishism, I might not be making too great a leap in examining the original title's Freudian connotations and asking why Whitman "buried" that original title. Was his own "arrow-tip" too vulnerable for public display, and in need of "hiding"? And might Boddo's overdetermined "body" also be a site of sexual "hybridity" and gender angst? Robert K. Martin's exegesis of the "two levels" of "The Sleepers" is certainly provocative in this regard: he claims that, in this poem, the "body [serves] as a metaphor for his [Whitman's] penis," a way for the poet to encode his sexual "perturbations" defensively, fearful as he was of "the exposure of the penis which may bring forth castration anxiety in a hostile world."23 While I won't be presenting Boddo entirely as some walking (or "limping") phallic symbol in the next section, the tale's many interpenetrating resonances between race and sexuality are certainly too great to be ignored.

\section{Boddo as Sexual Border Figure: "The Half-Breed" and Sexual Alterity}

$\mathrm{O}$, what a quiver was that which ran through the limbs-and as it were, the very soulsof all those assembled thereabout! . . . Then, with wild and ghastly visage, and with the phrenzied contortions of a madman in his worst paroxysm, Peter Brown dashed along the path and among them. His blood-shot eyes were fixed upon a hideous object dangling in the air. His head vibrated to and fro ... . "Quick! Quick!" came at last from his throat, in a gasping whisper . . . ("The Half-Breed" [EPF 290])

Boddo's very name bears echoes of "body," and maybe even "bawdy." (Even if, as I would guess, Whitman pronounced the name as "BOH-doh," the visual, "eye-rhyme" resonances of the first syllable's spelling would still be at work.) With his "long neck bent forward" (EPF 258), Boddo may well qualify as a phallic intrusion into the text, a figure whose "evil" can be roughly equated to the libidinal. As I attempt to draw parallels between sexual and racial alterity, Dana Phillips reminds us that the nineteenth-century worldview commonly associated "race" and "racial" with "racy," with much of the latter's current sexual connotations (297, 299; emphasis added). Young, too, notes that the nineteenth-century's infatuation with race was "also about a fascination with people having sex-interminable, adulterating, aleatory, illicit, interracial sex" (181). One immediately recalls the "voluptuousness" of both Margaret and the trapper's bride in such a context. 
In my attempt to turn a perhaps mundane reading of racial matters towards another political-cultural focus, that of sexual orientation, allow me to examine a few more scholarly pronouncements regarding race and sex before tackling Boddo's tale a second time. I would first turn again to Bhabha, and his assertion that, "[w]ithin the apparatus of colonial power, the discourses of sexuality and race relate in a process of functional overdetermination": in fact, Bhabha would read racial stereotyping itself as a form of Freudian fetishism (74). More à propos to Whitman, we have Michael Moon's contention that race and sexuality are two different encodings or "enfoldings" in Whitman's work, itself a free-floating corpus, at last, that renders "referents of" the various "discourses" of the body "indeterminate and fluid" (14). Via substitution and parataxis, Whitman creates an "interweaving of 'safe'-ostensibly nonsexual" discourses with "'dangerous' - explicitly sexual-discourses," thus "encoding 'forbidden' texts in 'permissible' ones" (6-7, 25). At last, such "metonymic substitutions" allowed Whitman "a liminal space" for representing "perhaps the single most increasingly threatened and stigmatized mode of bodiliness in his culture, the male-homoerotic" (11).

In a move crucial to my own argument, Moon traces Whitman's evocation of such "spaces"-through which "forbidden sexual desires can be explored without fear of persecution"- to the very "inception of his career," an encoding present even in the very early story, "The Child's Champion" [1841] (34). Furthermore, it is the "body" in Whitman that serves above all "as both the site and the object of prohibited desires" (35). And this body is not just any body, since the poet's "fluid" substitutions for homoeroticism usually included "his culture's . . . most highly charged figures for abasement and abjection": among them, "deformity" (15). Moon's attention to race and sex in conjunction will be addressed soon; but if I have dwelt too long on Moon's argument here, it was to arrive at (for starters) this connection, of a deformed body as possible "code" for homoeroticism.

As another tack by which to read Boddo as an overdetermined site of both race and sexuality, Martin, in his provocative reading of the "red squaw" episode in "The Sleepers" (LGVar. 1:115-116), notes that "homosexuality and miscegenation are the twin crimes so feared in American thought," and thus the putative lesbian relationship of the passage is a "double violation of taboo." 24 Martin then relates these "twin" taboos to Whitman's infamous reply to Symonds, ${ }^{25}$ in which the poet claims (according to Martin) that "he had broken the lesser of the two [i.e., miscegenation], lest he be found guilty of the greater [homosexuality]!" (87). If Martin's interpretation is true, Whitman followed Moon's formula, as it were, to the end of his life, encoding homoeroticism via another discourse-that is, race and miscegenation. If these 
latter seem almost as culturally loaded and problematic as sexuality, they still serve as a displacement, though an ultimately closely knit one at that, following Bhabha's reading of the "twin taboos" as two sides of the same psychoanalytical coin.

Robert Young counters another objection to my conflation of racial hybridity and homoeroticism: hybridity may seem like a "resolutely heterosexual category," but "in historical terms, concern about racial amalgamation tended if anything to encourage same-sex play (playing the imperial game was, after all, already an implicitly homo-erotic practice). . . . at one point, hybridity and homosexuality did coincide to become identified with each other, namely as forms of degeneration" (26). Hybridity, degeneration, and deformity, as codes for homoeroticism. Hybridity, degeneration, and deformity, as descriptions of-Boddo.

My case would be stronger if Boddo's “other" half, the Native American, were also implicated in Whitman's general system of homoerotic encoding. The possible phallic nature of Arrow-Tip's name may be a mere red herring by itself, but happily, Michael Warner provides a more viable route in his comment that Wind-Foot, that "noble youth" of an Indian in Franklin Evans (EPF 135), eventually does "what Indians do best in white American literature: die in erotically thrilling ways." 26 A closer look at the death scene corroborates Warner's assertion: as Wind-Foot's "shuddering" eyes close "in intense agony," his face gives a final "transient lovely look," and "a slight tremor" shakes his body as he dies (EPF 143). Folsom points to the "bathos" of both this scene and the death of "The Inca's Daughter" (73), a consistent theme in Whitman, it would seem, from that early poem (1840) to "Osceola" $(1890)^{27}$ - this latter Indian in possession of his own "arrow-tip," a "scalpknife." In sum, "the most extended poems that Whitman wrote about Indians were of them dying" (Folsom 76) —often in a manner that combined both pathos and eros.

"The Half-Breed" does not disappoint in this respect, although its erotic-death climax is given a special twist. The expected spectacle of Arrow-Tip's hanging is denied the reader; rather, the eroticism of the scene is displaced upon its internal, textual audience, especially Peter Brown (see epigraph to this section). Attempting to stop an unjust execution, Brown rushes to the scaffold "with wild and ghastly visage, and with the phrenzied contortions of a madman in his worst paroxysm": the man is so much in the throes of an orgasm, as it were, that his call to cut the rope is but a "gasping whisper" (EPF 290). It may well be that the original tale was "designed to dramatize the horror of capital punishment" (Scheick 36), just as Franklin Evans was designed to be a temperance novel, the homoerotic "encodings" of which will be discussed at a later point. But the "climax" - in more ways than one-of our story reveals such an excess of affect that one has to wonder if something else is going on here. 
Before arriving at Boddo's "body" per se, there may be other sexual and homoerotic encodings at work in the story. If Boddo is also the homoerotic abject, as I propose, a more positive example of what Whitman would later refer to as "adhesiveness," or male social bonding, is also present in "The Half-Breed," in the relationship between the schoolmaster Caleb and his favorite pupil, Quincy Thorne. Their several long talks and/or excursions together do actually further the plot at times, but they seem to exist mostly as a foil to the more "perturbed" racial/sexual tension that gets played out in the tale; the Platonic pair may thus be a more rose-colored, utopian side of a homoerotic binary, a further example of ambivalence and "splitting."

The absence of women in the tale also strikes one as odd, even for a frontier story. Peter Brown's fiancée seems to be the only significant female presence, and she serves as a mere audience for Father Luke's long monologue regarding his scandalous past. (Boddo is ignorant of this past, and Luke's calling him "my son" is a delicious piece of dramatic irony, masked as the reference is by the priest's religious persona [EPF 279]). The other female mentioned, Father Luke's Indian wifeBoddo's mother-is long dead: or is she? The primal scene of miscegenation, and Freud's Oedipal triangle, may still reside within the story, in the guise of Boddo, his father (and "Father") Luke, and the latter's own staked-out, womb-like spot of ground, a hidden, grotto-esque hut in the "side of a crag, all covered with bushes and hanging trees" (260). Boddo's several excursions into this uterine site, at one point in Luke's absence, may finally be read as an Oedipal trespass of sorts, implicated as these visits are in Boddo's general scheme of treachery and betrayal.

Another possible Freudian angle involves the resultant fear involved with such Oedipal strivings, that is, castration. Following an intriguing lead by Moon, and his comment on the "phallic and the castrated" implications of Whitman's "Broad-Axe Poem" (101), it may be significant that the colonizers/villagers are characterized by the axe-wielding occupation of clearing the land, lopping off trees' heads, rendering them stumps. ${ }^{28}$ What was a "tangled forest, roamed by the savage" (EPF 257) - and raw libido? - is now civilized and superego-ized, thanks to the advent of these "hewers of the forest" (290), proud warriors and censors in the fight against savagery - and sexuality? And against, at last, some of Whitman's own "savage" — and phallic —urges? Boddo's very presence is both the threat and the threatened in such a psychomachia, a figure of ithyphallic archaicism who must finally either "light out for the territories" or be "cut down"-and either way, be repressed. "Where id was, there shall ego be," to quote Freud, ${ }^{29}$ and to characterize the psychological rationalization of many a colonizing agenda.

Indeed, the territorial warfare against the "savage" and the Boddo/ body/libido may be Whitman's "civilized," guilt-imposing superego 
waging war on his own "body," as it were, and the encoded homoeroticism of the tale is thus constantly under threat-a tension embodied above all in Boddo's persecuted status, and maybe even in his motivation of revenge (following the psychoanalytical law that repressed drives will "have their day"). But I should first develop Whitman's own identification with "savagery" more earnestly, with the aid of Folsom, Young, and Whitman himself.

Ed Folsom's analysis of Whitman's identification with the "aboriginal" has already been noted, a "fascination" that would become a major component of "his ongoing poetic project" (69): Whitman even "came to think of his" free-form, New World poetry itself "as aboriginal" (8283). If the "friendly and flowing savage" of "Song of Myself" (LGVar. $1: 61)$ is an ambiguous signifier of both Native Americans and white pioneers, as the latter eventually "came to replace" the former in Whitman's writing, the ultimate result was Whitman's internalization of this "savage" component, an ability "to see the savage within himself" $(58,61) \cdot{ }^{30}$ I would contend that this identification with racial alterity has a sexual-alterity component, a belief supported by Robert Young's contention that the "identification of racial with sexual degeneracy was clearly always overdetermined in those whose subversive bronzed bodies bore witness to a transgressive act of perverse desire" (26). Boddo's "bronzed body" had a parallel in Whitman's own "bronzing" behavior and persona, a "browning" of his own body that occurs, significantly, during some of his more "Calamus" moments. In the Calamus poem, "Behold this Swarthy Face" (LGVar. 2:389), the Whitman persona puts on some Indian war-paint, if you will, as he describes his own "swarthy face" and "brown hands." ( $\mathrm{He}$ is also a bit of a laconic Indian himself here, with his "silent manner," his "natural and chalant" bearing. But such silence, in this context, is hardly surprising, with many of the Calamus poems hinting at a deep and troubled "unsaid.") In an 1887(?) letter, Whitman also frolics like some Rousseauian happy Native, luxuriating in a rural "outdoors" where he can spend "half the time naked or half-naked," and can become "all tanned \& red" (Corr. 3:99). ${ }^{31}$ But Whitman's "Indian"/Calamus impulses are not always such blithe celebrations of natural adhesiveness, as evidenced in the painful gestures of suppression in the Calamus poems - and in the disturbing representation of Boddo.

If Boddo does signify some darker, "guilty-thing-surprised" side of Whitman's homoeroticism, the half-breed's social status is indicative. $\mathrm{He}$ is reviled, spurned, scorned, teased, even physically abused, as if Whitman were displacing his guilt upon a body of racial alterity and abjection that is now thus further marked as the sexual Other. But I have also noted earlier moments of possible sympathy for Boddo and momentary attempts at resistance, even rebellion. (It may be signifi- 
cant, too, that Boddo is not punished for his crime.) Might these be "encoded" attempts on Whitman's part, unconscious appeals, at last, for an understanding of his own abjectness? Or is the tale itself an attempt through art to achieve some self-acceptance on the author's part? (And if so, is the attempt ultimately a failure?) At last, the "ambivalence" that Whitman felt towards the Native American may have been symptomatic of his own ambivalence towards his Calamus impulses.

Whitman's positive attitude towards the Native American included a privileging of Native languages: according to his American Primer, "All aboriginal names sound good." 32 But language, like race, is connected to sex via the inevitability of its hybridity. As Young tells us, nineteenthcentury Eurocentrism felt threatened by both biological interbreeding and the "interbreeding" of languages, or creolization (6): "Both produced what were regarded as 'hybrid' forms ... which were seen to embody threatening forms of perversion and degeneration and became the basis for endless metaphoric extension in . . racial discourse" (5). Whitman's own poetic diction would eventually become an ultimately creolized one, sprinkled as it was with working-class slang, elite scientific terminology, Indian place names (most notably, Paumanok and Mannahatta), and even pidgin French. Could this choice of diction be in part a "safer" encoding, or displacement, for an even more "threatening form of perversion," just as race and racial mixing, as I have been arguing, may have been similar codes? "Names are the turning point of who shall be master," to quote Whitman again: but they may also be the means to (at least unconsciously) question the master's monologism.

However, as dangerous as my assumptions about Whitman's psycho-biography have been, I'm even more wary of finding in the "encoded protests" I've been proposing some authentic "speaking for" the Native Other. But Moon, it deserves noting, is less reticent. His discussion of the intersection of race and gender in Whitman's "fluid" poetics claims that "Whitman repeatedly enfolds discourses of rebellion against racist oppression"-particularly in the 1855 Leaves of Grass-allowing voice, even empowerment, to "genuine others." These "others," moreover, include "Native American figures," who "bear a transitional significance in the race-and-gender system" of Leaves $(80,83)$.

Without breaking into some Nietzschean inversion of altruistic motives or speculating on the impossibility of a self transcending the boundaries of its own social/“Imaginary" constructs - for at last, as Sneja Gunew puts it, the "whole notion of authenticity . . . is one that comes to us constructed by hegemonic voices" (qtd. in Spivak 61)-I would still direct such a "voice of empowerment" back to Whitman's own egocentric concerns, reading such moves to a "genuine other" as calls for an understanding of his own abject (or "aboriginal") self-or conversely, impulses from a unconscious complex in need of expression and "life." As much as I have wanted to find some fully subversive "discourse of 
rebellion" in "The Half-Breed" on behalf of the racially marginalized, my best efforts have only indicated ways in which the tale's colonial discourse tended to deconstruct itself, a reading that might well be performed on any similar story from that time and milieu. The real "rebellion," if my argument works, involves not so much Boddo's racial body, but Whitman's own sexual one. And yet to follow the "enfolded" connection between race (especially the Native American one) and sex as it plays itself out in Whitman's earlier and later works would still no doubt prove enlightening, a path towards which I will wield my hewer's axe in this essay's final section.

\section{Conclusion: From Boddo to Bare Landscape}

Among the primitive inhabitants who formerly occupied this continent, it was considered very rude to pester a traveller or a guest with questions about himself. . . . (Franklin Evans [EPF 138]; emphasis added)

The red aborigines,

Leaving natural breaths, sounds of rain and winds, calls as of birds and animals, syllabled to us for names ...

...

Leaving such to the States they melt, they depart, charging the water and the land with names. ("Starting from Paumanok" [LGVar. 2:287])

Then blank and gone and still, and utterly lost.

("Yonnondio" [LGVar. 3:717])

As noted above, Whitman's "fascination with Indians" was "a crucial part of his ongoing poetic project" (Folsom 69), and I've argued that this interest was commonly tied to Whitman's fascination with the sexual body. In discussing the conflation of race and sex in "The HalfBreed," I've also indicated similar threads in other parts of Whitman's corpus, perhaps in a too rash and ahistorical fashion. A closer, more linear examination of Whitman's racial/sexual troping in previous and subsequent writings might further clarify the connection between the "savage," the hybrid, and the homoerotic libido, perhaps even discerning some evolutionary (or devolutionary) progression in Whitman's treatment of these "twin taboos."

Following ideas from Folsom about Whitman's eventual appropriation of the "savage" into both his own persona and his dream of a new white frontier "savage," ${ }^{33}$ I've already suggested, too, that Whitman may have more and more displaced his Native American subject matter upon more stylistic concerns of language and poetic persona. SánchezEppler has also noted that, in Whitman's later writings and revisions, there is often an "erasure of such historical markers" as race and miscegenation-most manifest in his removal of passages about slavery (82). 
I would join the "twin taboos" once again and ask whether this revisionism is an act of repression involving not only his guilt and ambivalence about the racially marked "body," but his guilt and ambivalence concerning his own "marked" body.

Franklin Evans, written before "The Half-Breed," deserves a closer look as a further indication of Whitman's early modus operandi. Its plot also involves miscegenation (Margaret herself, as Creole, and her marriage to Evans), as well as a Native erotic exoticism via the "WindFoot" interpolation. Even in this early work, the Native Americans are perceived as vanishing, or even already gone, as those "primitive inhabitants who formerly occupied this continent" (EPF 138). ${ }^{34}$ But these hints at disappearance are peripheral in comparison to the Indians' physical, even sexual, "presence," particularly in Wind-Foot's erotic deathscene discussed above.

The use of hybridity as a marker in Franklin Evans is given an ingenious spin by Sánchez-Eppler, who deems Franklin Evans himself, not Margaret, as the real "half-breed" of the tale: he thus displaces Margaret's actual mixed-blood status by assuming a hybrid "middle place" between Margaret and-the "fair-skinned"-Mrs. Conway (58-60). In line with the "enfolded" race/sex trope, this "mediation" is also a very sexual one, as evidenced by Evans' relationship with both women (a "convergence" of "shared" bodies) and by the eroticism of Margaret's strangling of Mrs. Conway (61-62). Sánchez-Eppler even relates the book's ostensible theme, drunkenness, to race, as "intoxication itself" becomes also "an issue of color": thus Evans' senses are "darkened" by drink (58-59), his choice of such a wife is blamed on drunkenness, and inebriation is thereby associated with the racial Other, just as "racy" sexuality is.

Returning to sex, then, it would be an easy step to construct a trinity of alcohol abuse, racial alterity, and sexual "degeneracy" if drinking and homoeroticism could somehow be connected. Thankfully, Moon has done that for me by claiming that the temperance theme in both "The Child's Champion" and Franklin Evans is another metonymic "encoding" of homoeroticism (53-55). And so the homoerotic body could be said to be present at last as in the central, title characters of both Franklin Evans and "The Half-Breed," metonymically reinscribed as the "drunken body" and the "mixed-blood body," respectively.

The multi-coded homoerotic body retains its prominence in the 1855 Leaves, as does, to a lesser extent, the racial other as possible "code" for that body. ${ }^{35}$ Aside from the well-known passages in "The Sleepers" (the "red squaw") and "Song of Myself" (the trapper's "red girl"), I might call attention to another possible sexual/Native-American enfolding, in the also oft-quoted passage from "Song of Myself" regarding the "prurient provokers stiffening my limbs." If one accepts for a moment 
the common contemporary reading that the entire passage concerns an upsurge of masturbatory, even homoerotic, libido, then the word "limbs" itself is a rather obvious signifier for a quite sexual signified, for one very specific "limb." But my main interest in this passage is the following: "The sentries desert every other part of me, / They have left me helpless to a red marauder" (LGVar. 1:39). If the passage is about the throes of sexual excitement, the "sentries" can be seen as the Freudian superego mechanism of censorship or suppression (the same mechanism, perhaps, that pities and yet scorns the onanist in other passages from the same poet). The "red marauder," then, is some id-inal/libidinal "invasion" or possession, with obvious associations of a "red," erect penis. ${ }^{36}$ But the phrase "red marauder" is also a metaphor that is perhaps so obvious that it may be passed over as a cliché: and yet, to revert to a New Criticism phraseology, if the tenor of the metaphor is maybe the penis or libido, the vehicle is certainly the image of the "red savage" raiding a white village, fort, or encampment. Once again, the "wild" and libidinal racial Other has been overlapped upon the Id as abject; and the Native-erotic "arrow-tip" continues as a fruitful vehicle for the Whitmanic "body."

But then Whitman's nerve to thrust the homoerotic body into his work seems to gradually diminish. Sánchez-Eppler's note of a later "erasure" in this regard is evident in Whitman's revision of the "trapper" passage in "Song of Myself" (LGVar. 1:11). Now the gun is absent. In my first attempt at this passage, I sided with the view that the gun was more ominous than reassuring, in terms of racial politics, and I still believe that. But by removing the gun, Whitman has also lessened the tension of the passage, as he would continue to lessen the sheer libidinal "friction" in much of his later poetry. There can be little doubt now about what I think the gun - and its editorial removal-also represents. Yes, Whitman has "sawed off" his "shotgun" again, so to speak, as if afraid of the social stigma and threat of "showing it all" and being "castrated," to invoke Moon's reading. And so, at last, Whitman "castrated" himself.

The common impression that the emphasis of Whitman's poetry moved from "body" to "spirit" - a vast over-generalization, to be surecould thus be explained via such a "castration"-repression theory, in which Whitman's homoeroticism became more and more sublimated (and repressed), as the "savage within" became more and more "outside" the "territory" of Whitman's ego consciousness - as much as his consciousness continued to assent to a recuperative assimilation thereof. Such a reading might also explain, in part, Whitman's switch from fiction to poetry, since the latter (as least as Whitman would practice it) allows for greater metonymy and displacement. And since the "complexes" of racial and sexual alterity are so affectively intertwined, it would 
be no surprise if Whitman's references to Native Americans would suffer a similar repression. One could immediately point to the 1865 poem, "Pioneers! O Pioneers!" (LGVar. 2:474-478) as indicative of this transition, a poem that goes on for many stanzas and many miles of frontier terrain, without a single mention of that aporia that is the Native American, as if the latter had been reinscribed as empty landscape.

But I am reminded that Folsom's study deals with several significant later utterances involving the Indian, in both poetry and prose. However, as Folsom himself perceives, the Native American seems to recede further and further into the distance (76-80, 92-98), their continued presence in his corpus actually an increasing "disappearance." I would point to just a few passages as evidence of this, beginning with the reminiscence from Specimen Days, in which Whitman speculates about the Native American presence on his own "native" place, Long Island: in sum, he conjectures that such people are "altogether extinct," but recalls a recent past in which a "few remaining Indians, or halfbreeds" were there, but then "left." 37 Whitman can write the word "extinct" with nary a quaver of his pen; moreover, he can now also invoke the notion of hybridity here as a way of justifying their extinction via some social/biological integration: the 1840's revulsion regarding miscegenation has now been transformed into a wishful-thinking appropriation.

Two very late poems on Native Americans emphasize above all their "repression," their passing. Whitman's tribute to the monument of "Red Jacket (from Aloft)" (LGVar. 711-712), despite the concrete, "bodily" (and Wordsworthian) evocations of "tree, or rock, or cliff," ends in the ether and the eidólons, as the specific Indian fades out via a Eurocentric simile, becoming a spirit who "Like one of Ossian's ghosts looks down." Likewise, "Yonnondio" is a "dirge" in which the "swarms" of Native Americans become "like clouds of ghosts" who "pass and are gone" (LGVar. 3:716-717). Yes, a "wailing word" is heard-Whitman's own, at last - but the result? The Native American - or the white American imago of the Native American-is constructed as a "blank" that is "gone and still, and utterly lost."

I realize that I'm struggling to navigate two co-theses here. To return to the second, Whitman's own homoerotic "body electric" may have also suffered enough cultural battering to have receded into the distance of his poetry and psyche, into Columbus-like passages to India and imaginative (however phallus-thrust) rides on a "Locomotive in Winter."But ultimately, Whitman's later efforts often leave this reader lost in a vast, but rather vacuous and etherealized, landscape, a landscape relatively devoid of a definitively marked racial or sexual body. And maybe this later (admittedly relative) repression of the specific marked body, ultimately determined, perhaps, by a nineteenth century 
too bent on colonization and progress to have time or consciousness for the racial and sexual abject, was prefigured by an earlier "period" in Walt Whitman's work-“The Half-Breed."

For even there, the poet had already written of an "unpeopled territory" of an "untrammelled" and "boundless nature": in fact, the western terrain is "all nature" (EPF 275) - as if anticipating a future time (and psyche) in which the tensions of sexual and racial otherness were wrapped safely in a monolithic song of one nation, one people, one common "ground." The author may have envisioned a time in which Boddo's tortured body had become a pure landscape, or a mere absence, just as Whitman's homoerotic body would become more "spiritually" sublimated, at last a singer of the "eidólons." And so ArrowTip's brother's lament that " "the Great Spirit has frowned upon our race" may also be a lament for the homosocial "adhesiveness" of Whitman's youth: now "“[w]e melt away, like the snows in spring"” (287), like Whitman's own neiges d'antan.

One might thus read his later poems and commentary on the disappearing "savage" as almost an elegy for his own abject and "aboriginal" homoerotic libido, both of which were just as threatened by the cultural onslaught of a later-nineteenth-century society hell-bent for positivist truths and logocentric certainty. In some ways, then, Whitman's own earlier agenda of the "body" was a "doomed" project of resistance against a will to power and knowledge that would increasingly other the "body" (be it Native or gay) and eventually render Whitman's dream of erotic individuality a nightmare of coercion and angst. What Boddo and similar "marked bodies" stood for ultimately became a pale shadow of erasure in Whitman's later poetry, as the writer seemingly succumbed to social forces greater than his own vulnerable "body" could withstand: at last, as Whitman's psyche settled into, or settled for, a Mickle Street respectability, ${ }^{38}$ Boddo-just as he did at the end of his own story-had long "fled the settlement" that was Whitman's later corpus (EPF 291).

\section{University of Nebraska-Lincoln}

\section{NOTES}

1 The Early Poems and the Fiction, ed. Thomas L. Brasher (New York: New York University Press, 1963), 258; hereafter EPF.

2 The Post-Colonial Critic: Interviews, Strategies, Dialogues, ed. Sarah Harasym (New York: Routledge, 1990), 10.

3 The Half-Blood: A Cultural Symbol in 19th-Century American Fiction (Lexington: University Press of Kentucky, 1979), 36, 37.

4 Disseminating Whitman: Revision and Corporeality in Leaves of Grass (Cambridge: Harvard University Press, 1991), 80. 
6 At the time he wrote "The Half-Breed," "most of Whitman's attitudes toward the Indian" were "little more than a melange of savagist stereotypes" (Ed Folsom, "Whitman and American Indians," in Walt Whitman's Native Representations [Cambridge: Cambridge University Press, 1994: 55-98], 74). For Whitman's ambivalent and changing racial views, including his growing conservatism, see Folsom's essay (e.g., 62-65); Scheick 36; and Reynolds 123-127, 372-373, 469-473, 476-477, 483. According to Dana Phillips, "Whitman treats his images of the Other . . . as basic 'specimens,' to use one of the poet's favorite words" ("Nineteenth-Century Racial Thought and Whitman's 'Democratic Ethnology of the Future'" [Nineteenth-Century Literature 49 (1994), 289-320], 294).

7 Folsom 64, 74-76, 92-93. Sheick, too, discerns a "sympathy" on Whitman's part for the "dispossessed" full-bloods, but points to Arrow-Tip's death as an emblem of their eventual eradication (36-37).

8 Regarding Whitman's similar puzzlement over such reticence in his "Indian Bureau Reminiscence," Dana Phillips says that, "[b]y the end," they've become "veritable wooden Indians" (312).

9 Karen Sánchez-Eppler, Touching Liberty: Abolition, Feminism, and the Politics of the Body (Berkeley: University of California Press, 1993), 75.

10 Quoted in Cyrus R. K. Patell, "Comparative American Studies: Hybridity and Beyond," American Literary History 11 (1999), 172.

11 EPF 204, 209. Similarly, Father Luke's lame excuse for fathering the lame Boddo is-sheer "tedium" (272)!

12 Leaves of Grass: A Textual Variorum of the Printed Poems, ed. Sculley Bradley, Harold W. Blodgett, Arthur Golden, and William White (New York: New York University Press, 1980; 3 vols.), 1:11-12.

13 Sánchez-Eppler 81, 52, 54, 56. According to this critic, Whitman's use of miscegenation as "an extremely potent instance of mediation" goes back to his early, seminal "master \& slave" notebook entry, an attempt "to reconcile racially distinct bodies" $(59,50)$ : for even this slave-and-master metaphor is a "powerful image for the commingling of body and soul [that] reiterates the scene of miscegenation" (81).

14 Sánchez-Eppler 54, 56-57, 70, 79-80, 82; moreover, she finds Whitman's "reliance on blood" as a racial marker "disturbing" (57).

15 The Caliban angle is my own, not Scheick's. The parallels with The Tempest would make a monograph in themselves: like Caliban, Boddo has a "native" knowledge of the terrain: he can find a "dead squirrel" hidden anywhere "within five miles" (EPF 260); his Great White Father, Father Luke, is a hermit who lives surrounded by "books and paper" (261) - a man of "mystery" (269), like Prospero. And like Prospero, this recluse has (at least initially) some misanthropic tendencies in him. Furthermore, Father Luke's very reason for being near the village is to reform, civilize, and convert Boddo from his "besotted nature" (273), just as Prospero would civilize Caliban.

16 Robert J. C. Young, Colonial Desire: Hybridity in Theory, Culture and Race (London: Routledge, 1995), 6; see also Phillips 297, 300, 305-306.

17 Young 18. Major theorists of this ilk included the "notorious" Count Gobineau (99-103) and the beloved American naturalist - and childhood hero of mine-Louis Agassiz (148-150). 
18 "The Primer of Words," in Daybooks and Notebooks, ed. Edward F. Grier (New York: New York University Press, 1978), 3:756.

19 If it seems as if I'm dealing with Boddo as simply the "Red" Other at this point, it's because, as I argued in this essay's first section, he is also bearing the brunt of antiIndian racism. Because of Arrow-Tip's "positive" stereotyping, Boddo becomes the site of displacement and projection for white attitudes towards the Indian per se, a point I will develop momentarily.

20 "The Other Question: Stereotype, discrimination and the discourse of colonialism," in The Location of Culture (London: Routledge, 1994), 66-84; see especially 6970, 74-77. Bhabha's four-term binary consists of the "metaphoric/narcissistic and the metonymic/aggressive," with the usual Lacanian intent of "metaphoric" (e.g., identification, substitution) and "metonymic" (e.g., lack and displacement) (77). Robert Young, similarly, perceives "an ambivalent driving desire at the heart of racialism: a compulsive libidinal attraction disavowed by an equal insistence on repulsion" (149); he deems "questions of racial miscegenation [as] the soft underbelly" of colonialism, "fuelled by the multifarious forms of colonial desire" (175).

$21 \mathrm{My}$ analysis of Whitman's "need" for the Native American-finally, the imperial ego's need for the "shadow" that is the colonized Other-fits well with Gayatri Spivak's postcolonialist agenda (though the colonial-imperial contexts are different): her aim is "to show how they-the makers of English literature-need us" (the Asian Indian "Other") and at last "to see how the master texts need us in the construction of their texts without acknowledging that need" (73).

22 Such guilt-displacement was at work in the very conception of the "noble savage," as Folsom notes: even the "most advanced" Native Americans had some "vestigial vice," allowing whites to readily conceive of their extinction (or cultural absorption), "absolving" the whites at last "of guilt" (76).

23 "Whitman's Song of Myself: Homosexual Dream and Vision," Partisan Review 42 (1975), 85.

24 Moon also claims this passage to be about both "race" and "homosociality," a "'fluid' scene of desire" (84-85). Noting that such binary mergers as racial hybridity or cross-gendering often overlap within a single "identity," Patell proposes the term "polygenetic" rather than "hybrid" to describe such multiple intersections of identity modalities (178-179).

25 The Correspondence, ed. Edwin Haviland Miller (New York: New York University Press, 1961-1977), 5:72-73.

26 "Whitman Drunk," in Breaking Bounds: Whitman and American Cultural Studies, ed. Betsy Erkkila and Jay Grossman (New York: Oxford University Press, 1996: 3043), 36.

27 EPF 6-7; LGVar. 3:743.

28 The colonization began with one "adventurous settler," whose efforts led to a village of almost 300 people in less than seven years (EPF 257).

29 New Introductory Lectures on Psycho-Analysis [1932], in The Standard Edition of the Complete Psychological Works of Sigmund Freud, ed. James Strachey (London: Hogarth Press, 1964; 24 vols.), 22:80.

30 Moon would consider the "free and flowing savage" passage as another "emblematic embodiment" of a "specular, male-homosocial 'fluidity" —if it weren't for the 
Native American's aloof taciturnity (86-87), a refusal to be properly, socially "fluid," as it were.

31 I owe both the Calamus-"savage" connection, and my specific examples, to Ed Folsom.

$32 D B N$ 3:743; see also 3:752. See also Folsom $80-88$, for a thorough analysis of Whitman's obsession with "aboriginal" languages.

33 Folsom 58-62, 69-72.

34 Interestingly, the Wind-Foot interlude is introduced by a reference to Indians and rum (133), with the implication that their eventual eradication is at least partly their own fault for being too genetically weak to resist its influence.

35 Moon 26-87. The first chapter of Moon's book discusses "The Child's Champion" and the 1855 Leaves in conjunction, vis-à-vis this theme (26-58); for his treatment of sexuality and the racial (and gendered) Other, see 80-87.

36 Martin's reading that it is someone else's "invading" penis need not be- $\mathrm{uh}-$ pushed (93).

37 Prose Works 1892, ed. Floyd Stovall (New York: New York University Press, 19631964), 1:11.

38 I am probably projecting my familiarity with Wordsworth's poetic "apostasy" upon Whitman here and assuming a too similar progression for all such revolutionary poets whose long lives exposed them too much to the "light of common day," to the detriment of their art. But given my own image of Wordsworth as the prototype of a Romantic poet who lived too long, as it were, who "sold out" his radical youth by turning to the establishment for financial security and-worse yet-"ruining" much of his earlier poetry by revising it in accord with a more conservative orthodoxy, I have read Reynolds's "cultural" biography of Whitman as nearly a recasting of Wordsworth in the New World, with the "Sage of Grasmere" reincarnated as the "Good Gray Poet." 